\title{
Earlier Times
}

An excellent example of the power of the Himalayan place of Kedarnath as a whole is fictional, found in a short detective story written in Bengali by Satyajit Ray (2000) and translated into English by Gopa Majumdar: "Crime in Kedarnath." Ray wrote these stories as didactic travelogues about different regions in South Asia that educated younger readers about cultural diversity and history. While fictional, the stories skillfully and accurately portray the worldview and mores of his mid-twentieth-century, middle-class Bengali audience, who over the last century and a half have constituted one of the core visitor groups to Uttarakhand. In this episode the crime-solving trio of Feluda Mitter, Lalmohan Babu, and Feluda's nephew Tapesh are drawn to Kedarnath on a case and are speaking with a fellow Bengali they meet on the journey. He says to them:

"I have been to Kedar and Badri twenty-three times. It's got nothing to do with religious devotion. I go back just to look at their natural beauty. If I didn't have a family, I'd quite happily live there. I have also been to Jamunotri, Gangotri, Gomukh, Panchakedar, and Vasukital. Allow me to introduce myself. I am Makhanlal Majumdar." Feluda said, "Namaskar" and introduced us. "Very pleased to meet you," said Mr. Majumdar. "A lot of people are going to all these places now, thanks to road transport. They are not pilgrims, they are picnickers. But, of course, buses and taxis can do nothing to spoil the glory of the Himalayas. The scenic beauty is absolutely incredible." (Ray 2000, 305)

Yet as the story continues it strikes a different tone:

Ramwara [Rambara, the midway point between Gaurikund and Kedarnath] was at a height of 2500 meters. The scenery around us was absolutely fantastic. Lalmohan Babu went into raptures, recalling scenes from the Mahabharata. He declared 
eventually that he would have no regret if he fell and died on the way, for no one could have a more glorious death. ... In the remaining three and a half miles, only one thing happened that's worth mentioning. The tall spire of the temple of Kedarnath came suddenly into view after leaving Ramwara. Most of the travelers stopped, shouting, "Jai Kedar!" Some folded their hands and bowed, others lay prostrate on the ground. But only a few moments after we resumed walking it vanished behind a mountain. We could see it again only after reaching Kedarnath. I learned afterwards that the brief glimpse we had caught earlier was considered a special darshan. It was called deo-dekhni. . . . It was half past five in the evening by the time we reached Kedarnath. It had not yet started to get dark, and the mountain tops were all shining bright. It is impossible to describe what one feels on reaching a flat plateau after climbing uphill for several hours on a steep and narrow road. The feel uppermost in my mind was a mixture of disbelief, reassurance, and joy. With this came a sense of calm, peace, and humility. Perhaps it was those peaks which towered over everything else that made one feel so humble. Perhaps it was this feeling that evoked religious ardour, a reverence for the Creator.

A large number of people were sitting, standing, or lying on the rocky ground, overcome with emotion, unable to say or do anything except shout, "Jai Kedar!" . . I had expected Lalmohan Babu to want to rest after our difficult journey. But he said he had never felt more invigorated in his life. "There is new life in every vein in my body," he said. "Tapesh, such is the magic of Kedar." (Ray 2000, 2:321-22)

The "magic of Kedar" described above results from the experience of the place as a whole combined with the difficult journey that precedes it. For the conversations undertaken in this book it may be viewed as an eco-social experience of Kedarnath that could, depending on the frame of analysis deployed, be understood as "religious" and/or Hindu. This example, at this moment in our historical narrative, is designed to provoke a question in the mind of the reader, a question that in colloquial Hindi is often expressed in this way: "Kahan se kahan tak?" (lit. "From where up to where?" or more figuratively "How on earth did we get from there to where we are now?"). By what processes did Kedarnath transform from a famous premodern place of pilgrimage in the Himalaya, inhabited by a powerful and complex god, to a site where a group of travelers might go together for a combination of reasons that include everything from religious devotion to a kind of adventurous curiosity that drives certain forms of leisure travel? In what follows I will trace how the complex premodern patterns charted in chapters 1 and 2 transformed into more recent patterns.

Religious travel to Kedarnath and to the Garhwal Himalaya more generally was part of the broader transformation of the somewhat specialized practice of tirtha yatra in premodern South Asia into a broad, popular practice of yatra supported by a growing rail infrastructure during the colonial period (Lochtefeld 2010). During this time and into the present, it has been well attested that pilgrimage and tourism have been increasingly conflated (Gladstone 2005). However, in Kedarnath and the Uttarakhand Char Dham, because of the relatively inaccessible Himalayan 
geography and the social history of Garhwal and Kumaon, these developments took a distinctive turn. Around the time of statehood in 2000, there was a massive rise in the number of yatris coming to Kedarnath, causing an accelerated spatialization of capital, a rapid influx of money connected to pilgrimage tourism that spread throughout the economic catchment area of the Uttarakhand Four Abode Pilgrimage to the shrines of Yamunotri, Gangotri, Kedarnath, and Badrinath. ${ }^{1}$ This phenomenon ran precisely counter to the kind of sustainable Himalayan development imagined during the creation of the state in 2000. The earlier remoteness of the region intensified the impact of the changes.

Over time the Garhwali setting manifested a tense, emergent interplay of the local lifeworlds of small Himalayan valleys with larger-scale political, economic, ecological, and Puranic frameworks for thinking about the identity of the region. Arun Agrawal and K. Sivaramakrishnan $(2003,21)$ have characterized some aspects of what I am terming a "tense, emergent interplay" as a distinctively Uttarakhandi regional modernity in which the sense of modernity is "more tied to place, but the place-related ties themselves are produced by a belief in the political and economic discrimination faced by those living in Uttarakhand." ${ }^{2}$ As part of this emergent "regional modernity," a regional understanding of the idea of "Himalayan nature" emerged, shaped in part by colonial and postcolonial discourses about the picturesque Himalaya, hotly contested practices of natural resource extraction, and the desire of hill peoples for social and political autonomy (Linkenbach 2006, 2007). Over time Kedarnath became one of the most prominent sites in the region to be associated with this set of discourses. The rising tide of pilgrimage tourism began to crest around the time of the creation of Uttaranchal/Uttarakhand as a separate state in 2000, and Kedarnath was one of the places where the interplay of these different forces was the tightest. Kedarnath valley locals began to lose touch with older ways of living and working in Kedarnath. In the Kedarnath valley, locals and visitors understood these changes as both arising from the power and importance of Kedarnath and at the same time detrimental to it. In these discourses, Kedarnath, whose power and importance were constituted by the enmeshing of Shiva with the natural Himalayan environment, pulsed as one of the centers of these webs of region and state. The diverse set of Shaiva and Shakta geographic imaginaires charted in the last chapter were partially decentered but remained influential and efficacious.

\section{GARHWAL}

From the thirteenth to the twentieth century, Garhwal differed from many other regions of the Indian subcontinent with regard to its position in political, cultural, and economic networks. Sites such as Kedarnath drew people from outside the region. On the basis of even a conservative historical assessment of the antiquity 
of the site, it is evident that from the thirteenth century onward Kedarnath was on the map of important tirthas visited by kings, renunciants, and those devotees with enough time and courage to make the journey. There are entries about yatra to Kedarnath in important dharmashastra digests (Vīramitrodayah 1906; Lakșmīdhara 1942; Kāne 1953). Beginning in the twelfth century, the rule of the Katyuri dynasty ended in Garhwal and Kumaon, and rulers from the Malla dynasty in western Nepal became active in the region. The area where Kedarnath is located underwent considerable political fragmentation. The next four centuries saw the practice of yatra to Kedarnath and Badrinath unfold primarily as a journey through a series of numerous small, competing principalities. Each of these principalities often centered on its own fort, or garh, from whence comes the region's modern name of Garhwal, in Hindi, "the place of forts." This period ended with the consolidation of the Garhwal region into a single kingdom in approximately the sixteenth century by Ajay Pal of the Parmar/Panwar dynasty and the split of Garhwal and Kumaon into separate, competing regions (M. Joshi 1990, 63-64).

The relative geographic remoteness of the region may have been one of the factors that slowed the region's embrace of developments and networks originating from the plains. For example, it may have drawn out the processes through which Kedarnath became incorporated into transregional Shaiva and Puranic sacred networks. It also meant that traditional accounts of Kedarnath, in contradistinction to those of North Indian sites such as Braj or Somnath, do not include a narrative of destruction or the lapse of tradition sometimes associated with periods of Muslim rule. Rather, they often celebrate Shankaracarya's arrival in the region as rescuing the region from its control by Buddhists. Garhwal and Kumaon during these centuries became very involved in Indo-Tibetan commerce, and the transit fees from this trade and the pilgrimage activity of yatris were the major sources of income for the region (Rangan 2000). The Garhwal region also remained relatively politically autonomous during the Mughal period (Negi 2001, 17). The geography of the region generally and of the Kedarnath valley specifically meant that Garhwal (even compared to Kumaon) remained on the periphery, and out-of-the-way sites like Kedarnath even more so. While important for the yatra trade, the Kedarnath valley was relatively unimportant for commercial trade between Tibet, central Asia, and North India because the primary northern pass proceeds through Badrinath, whereas Kedarnath is closed off to the north by glaciers.

This geographic history has meant that in recent centuries Garhwal has exhibited a blend of local, animistic tradition with broader frameworks that today might be termed "Hindu and/or Buddhist," a mixture that is to widely varying degrees characteristic of a wide belt of Himalayan religious traditions and cultures stretching from modern-day Tajikstan, Afghanistan, and Pakistan to the northwest of India to China, Tibet, and Nepal in the north to Bhutan and the Indian state 
of Arunachal Pradesh in the east. Relative to the North Indian plains, the region known today as Uttarakhand has been a border zone where groups moving up from the North Indian plains mingled with arrivals from central Asia and indigenous groups already resident in the area. The worship of natural elements (Sanskrit: bhuta) in this region shades into shamanic interactions with placespecific local deities, which in turn shades into large-scale cosmological understandings that include deities such as Vishnu, Shiva, and forms of Devi (Dhasmana 1995; Purohit, Negi, and Negi 1995). In Garhwal specifically, as opposed even to Kumaon and to many other regions in this Himalayan belt, there is additionally a distinctive depth to the overlap of local Himalayan traditions with the Sanskritic worlds of the Veda, the Mahabharata-Ramayana, and the Puranas (Sax 2011, 2002, 1991; Nautiyal 1994). This complicated social history also feeds into how different groups resident in what we now term Uttarakhand have historically viewed one another (M. Joshi 2011).

The region's relative isolation was breached when Gurkha kings of Nepal briefly and successfully annexed large portions of Garhwal and Kumaon in the late eighteenth century, beginning in Kumaon in 1790. The British were able to use the pretext of rescue from the occupation of Garhwal and Kumaon to develop a foothold in a region that contained an important route to Tibet, central Asia, and Russia through Badrinath. This meant that the region was both strategically important, because it connected northern India to Russia and China, and commercially important because it provided access to the Silk Road and contained the valuable natural resources of "pashm (Cashmere wool), gold, borax, and salt" (Rangan 2000, 73). After defeating the Gurkhas in 1815, the British annexed Kumaon and part of Garhwal, leaving what is now known as Tehri Garhwal as a princely state in the hands of the Garhwali king Sudarshan Shah, who subsequently established the capital of his kingdom in the town of Tehri. ${ }^{3}$ The British struck a series of treaties with the Tehri court. Through these treaties, the British made sure that the parganas of Nagpur (containing Kedarnath) and Painkhanda (containing Badrinath) became part of British Garhwal rather than Tehri Garhwal and over the next century repeatedly rebuffed the Tehri court's requests that the administration of Kedarnath and Badrinath be fully in royal control (India Office 1895; Traill 1823; Crown Representative's Records 1936; India Office 1942, 46; Rawat 2002, 19-20; Negi 2001, 24-25). British Garhwal itself became part of the province of Kumaon. Garhwal's geographic autonomy from Mughal rule notwithstanding, Garhwali political administration incorporated standard Mughal administrative patterns such as the pargana-patti system of land division and taxation that served as the basis for this division (Gordon 1985). This became the basis for tax collection in British Garhwal, and the Kedarnath valley came under British rule.

As rulers who were concerned with both profit and the preservation of their version of order, the British had several areas of particular interest in British 
Garhwal. Haripriya Rangan (2000, 70-71) has observed that in the "regional economy of Garhwal" in the eighteenth century "transit duties" generated from yatris were one of the most significant forms of revenue in the region, along with export and transit taxes charged for mining and the extraction of other resources like timber. The British aimed to build on this commercial characteristic of the region. This focus on resource extraction took several early forms: an emphasis on the production of tea, hemp, sugarcane, cotton, and rice. In the second half of the nineteenth century, after the formal declaration of direct rule by the British government in 1858, Garhwal was no longer as profitable a site for these agricultural products. The emphasis in British Garhwal shifted to what had become the only commercially viable natural resource that could be profitably extracted from Garhwal at the time: timber. These large-scale extractive relationships to kedaramandala mixed in with the older, diverse Shaiva, Shakta, and Himalayan ways of conceptualizing, experiencing, and enacting connection with Himalayan landscapes, and resistance to these extractive movements drew to some degree on these older, already emplaced patterns.

The impact of British colonial presence on the natural environment was already predominant in a story that, in the nineteenth, twentieth, and now twentyfirst centuries, has become depressingly familiar-a story of resource extraction, widespread deforestation, and damming of rivers, and in a more general sense the large-scale transformation of human relationships to the natural world into relationships characterized by a sense of often short-term instrumentality. These relationships in turn refract through the pernicious prisms of large-scale industrialization and the discourses and practice of development, something I address more substantively in chapter 6 . In a region like Garhwal this has meant that over a period of two hundred years a pattern built up in which Garhwalis became the often unwilling providers of resources for people living outside Garhwal in ways that were profoundly disadvantageous.

\section{FORESTS}

The preservation, management, and sale of timber would be of central concern to the British and later Indian governments for the next century and a half. The new Indian rail network (begun in 1864) was one of the catalysts behind the development of a Forestry Department whose primary aim was to manage, preserve, and extract timber to be used in the construction of railway sleeper cars (Guha 2000, 37). The creation of a Forestry Department set in motion an almost century-long conflict. On one side were timber companies from outside the region and the colonial and postcolonial iterations of local, regional, and national governments who supported them along with specific organs of the government such as the Forestry Department. On the other side were local 
Garhwalis and Kumaonis, notably the local women who were the primary gatherers of wood. They resented how the Forestry Department took over what had been commonly held land, cut down far too many trees, encouraged the growth of the kinds of trees that would support the timber industry, and denied locals access to what had formerly been their own local natural resources. Extralocal control and cutting of trees also challenged the political and religious authority of local deities who "owned" particular territories in which forests were located (A. Kumar 2011, 90. ${ }^{4}$ These tensions, along other causes for resentment against British rule, occasionally crystallized into demonstrations, strikes, and protests, beginning in the late nineteenth century (Rawat 2002, 130-51). After Independence the Indian Forestry Department continued down the same path (Gadgil and Guha 1995, 23). These tensions eventually created the conditions for what would emerge in the 1970 s as the Chipko movement, now world-famous for their very successful use of the nonviolent, Gandhi-inspired technique of tree hugging (the name Chipko derives from the Hindi verb chipakna: cling, stick, adhere) as a way to protest the management and felling of local trees by the Forestry Department and commercial timber companies. This movement was championed by environmentalists such as Chandi Prasad Bhatt, Sunderlal Bahuguna, and Vandana Shiva and was famously spearheaded by local women. ${ }^{5}$ The village of Fata in the Kedarnath valley, just north of the temple of Mahismardini, was one of the Chipko movement's important early sites of nonviolent resistance (Guha 2000, 157-58). Today Fata is one of the places in the Kedarnath valley where one can board a helicopter to fly to Kedarnath.

\section{RIVERS}

A second focus of the British in the region was the control of rivers. In the mid-nineteenth century the British decision to canalize the Ganges River near Haridwar to alleviate the impact of a recent large-scale drought on the IndoGangetic plain led to wide-scale protests in Haridwar and caused many local groups to unite against this British initiative (Lochtefeld 2010, 88-96; Rangan 2000, 87-90). Approximately a century later, the decision of the Uttar Pradesh and central governments to begin construction of a large-scale hydroelectric dam on what becomes the Ganges River just below Uttarkashi in Tehri Garhwal in order to generate electricity and provide water for use outside the region raised another round of massive, ongoing protest and controversy. The Tehri Dam is a massive civil engineering project, a structure of staggering scale located in a region well known for its historic and potential future seismic activity. Its construction, symbolic of a Nehruvian vision of large-scale development, was seen to be of little benefit to Garhwalis themselves. Emma Mawdsley $(2005,9)$ observed that the "displacement from land" and "environmental damage" created by the construction of the dam 
disproportionately affected predictably vulnerable groups: "the poor, women and rural people of this marginal mountain region." Resentment against hydroelectric projects on the Ganga continued to build and diversify. One of the most recent chapters in this story, chronicled by Georgina Drew $(2017,14)$, has been the surge of environmental activism that produced the central Indian government's designation of part of the Bhagirathi Ganga as an "Ecologically Sensitive Zone."

Haripriya Rangan (2004, 213-24) observes that a lack of sufficient government relief for the destruction caused by serious floods, landslides, and erosion (particularly in the 1970s), characteristic of larger trends in the "economic marginalization" of people in the Garhwal Himalaya, was a tragic consequence of this national development model that fueled considerable regional resentment. Anger against such large-scale hydroelectric projects overlaid and joined the nexus of resentment, social and economic contestation, gendered resistance, and allegiance to local and regional patterns of Himalayan religious sentiment connected to the battle over timber. Linked concern about control of, and respect for, trees and flowing water and the small-scale and sustainable ways of being associated with such respect influenced the vision for the separate state of Uttarakhand, but the continuation of destructive and environmentally unsustainable practices in the new state undermined that vision and fueled a sense of betrayal brought to crisis point by the floods of 2013 and the response of the state government in the aftermath.

These colonial and postcolonial developments joined the Himalayan landscape conversation (recalling Ingold's idea of "landscape" as an emergent conversation between human and other types of interdependent organisms all based in the natural world), a conversation already infused with diverse religious understandings of the enmeshing of Shiva with the Himalayan terrain and his close relationship with the flowing waters of the Goddess and the pervasive presence of local deities. The shakti of Shiva, of the rivers, and of the Himalaya, distinctively resident as it was in Kedarnath, began to be treated as a natural resource to be mined and controlled and pictured. But another important change was building force as well: the emergence of a regionally specific set of discourses about the idea of "nature" (Hindi: prakriti) that further framed the production of landscape, identity, and the experience of place in Garhwal, especially in places such as Kedarnath. I return to these developments later in the book in the context of a discussion that looks at how understandings of "nature" overlap with the divine powers of Shiva and Devi.

\section{YATRA REGULATION AND TRANSPORTATION}

The British government in India was deeply involved with the regulation and support of pilgrimage across the subcontinent in numerous ways, an endeavor closely bound up with the control and management of fields, forests, and rivers 
because of the necessity for transport infrastructure in the form of roads and railways and the tax revenue to fund that infrastructure. The Archaeological Survey of India and its practice of what Toni Huber (2008, 252-53) called the "distinctive colonial phenomenon of monumental archaeology" was, for example, a primary catalyst for the renewed importance of Bodh Gaya as a site of Buddhist pilgrimage for Buddhists outside the Indian subcontinent. The assembling of Indian Muslims for travel on the Hajj pilgrimage to Mecca, and the potential of the transmission of cholera from Europe to India via Hajj travel to and from Mecca, produced legislation aimed at controlling these politically suspicious potential problems (Mishra 2011, 15-19). Disease prevention was also of concern for the government of British Garhwal, as was the regulation of sanitation at pilgrimage places more generally (Khalid 2008). Assembly at large melas such as the Kumbha mela was viewed with suspicion for the same reasons (Mishra 2011, 15; Maclean 2008, 12). Groups of Shaiva ascetics were of British governmental concern at this time because they were seen as sources of conflict, axes of political power, and a potential pool of military recruits (Pinch 2006, 77).

The increased number of yatris in the nineteenth century was one of the indications that yatra in South Asia had begun to change from an elite and renunciant practice to something that regularly included members of society from diverse social and economic groups. This change, which in some cases might have meant a threefold increase in the number of visitors to specific places of religious significance, was facilitated by better transportation, the abolition of "pilgrim taxes," the rise of a new kind of "conspicuous piety" by kings, and "new men who built up their fortunes through the service of the British" (Yang 1998, 134; Bayly 1988, 159). Significantly, building on an observation by Ashish Nandy (1980, 7) about nineteenth-century views of the contested practice of sati, Yang (1998, 138-39) observes that the act of pilgrimage "may even have gained in status and currency over the course of the colonial era" and "may well have represented a way of expressing 'conformity to older norms at a time when these norms had become shaky within"' (see also see also Maclean 2003, 891). Yang (1998, 137) observes that the rise in the popularity of pilgrimage centers in the nineteenth century also produced new forms of religious advertisement: vernacular renderings of Sanskrit works celebrating the greatness of specific deities and deity-related places (Sanskrit: mahatmya) in the form of printed pamphlets.

\section{THE RELIGIOUS ENDOWMENTS ACT}

The money associated with important pilgrimage places created many entanglements for British administrators and for the British government more generally. The massive amounts of revenue from land owned by temple deities and from funds and goods donated to temples produced numerous situations where colonial 
administrators found themselves, first in an ad hoc modality and then in an increasingly formal way, embedded in Hindu temple administration in order to realize profits from revenue collection and to adjudicate disputes between local stakeholders for whom they had become another group of local and regionally powerful political actors (Yang 1998, 134; Presler 1987, 15; Appadurai 1981). In these contexts the British found themselves struggling between conflicting policy imperatives: the responsibility (once that of the king) to maintain order and to ensure the proper handling of temple funds and the desire not to interfere in religious matters (Presler 1987, 15-56; Appadurai 1981, 105-38; Dube 2001; Reddy 2014, 147-95).

From 1817 to 1839 the East India Company formally involved itself in the financial and administrative management of temples and mosques (Mudaliar 1976, 22; Presler 1987, 16-17). Then in 1839 it attempted to extricate itself from this involvement and practice a "policy of neutrality towards religious institutions" (Mudaliar 1976, 22; Presler 1987, 19). In the middle of the nineteenth century, when Britain formally annexed India as part of the British Empire, this situation changed again. The British government attempted to officially and legally withdraw from formal involvement with Hindu temple administration and instead to place temple administration in the hands of locally constituted committees or "area committees" of temple trustees drawn from among the different groups of local stakeholders with traditional claims to administrative authority. The operating procedures of this new organizational scheme were meant to ensure the proper management of temple funds generated by property revenue, donations, and fees given for ritual services. The formal legal mechanism of this withdrawal was the Religious Endowments Act XX of 1863 (Mudaliar 1976, 22-23). However, this act did not immediately obtain in all cases. Rather, the state would create an amendment that would extend and shape the act so that it could apply, with stipulations that made sense for the specific case, to a particular temple or set of temples. Initially this happened when a complaint regarding temple management rose to the level of a civil suit against temple trustees or members of the local "area committees" (Presler 1987, 24-25). As a result of this tortured dance of power, policy, law, and money, there were numerous multiact legal dramas involving kings, priests, and colonial administrators over the course of approximately two centuries. In the case of Badrinath and Kedarnath, this process began with the Shri Badrinath and Kedarnath Temples Act of 1939 (Husain 1965; Badri-Kedar Temple Committee n.d.). ${ }^{6}$ According to the "prefatory note" of the act, which was later extended to include Kedarnath,

The Badrinath Temple which is one of the foremost sacred places of Hindu pilgrimage in India is situated in the Garhwal district on the heights of the Himalaya. Under the scheme of 1899 at present in force its management is in the hands of the Rawal, while the Tehri Durbar is invested with certain supervisory powers. The defective 
nature of the scheme has been the source of constant friction between the Rawal and the Tehri Durbar. As a result, supervision of the temple has suffered, its income has been squandered and the convenience of the pilgrims has been neglected. The unsatisfactory condition of the temple which has existed for a long time was specially brought to the notice of Government by the Hindu Religious and Charitable Endowments Committee in 1928. Since then public agitation has been continually pressing for reform in its management. The Bill which is now introduced seeks to remove the chief defects of the present scheme. It restricts the Rawal to his priestly duties and places the secular management of the temple in the hands of a small Committee which would be partly elected and partly nominated. It preserves at the same time the traditional control of the Tehri Durbar; while adequate powers have been reserved for Government to guard against mismanagement by the Committee.

Later on, the act clearly defines "Temple" as referring to both the "Temple of Shri Badrinath and the Temple of Shri Kedarnath" (Husain 1965, 525), Today the Samiti generates its own revenue and has a board composed of selected and elected officials, some of whom must be from particular regions of Garhwal. It runs the Badrinath and Kedarnath temples, along with a host of ancillary sites. It also funds and manages several educational charitable institutions, such as Sanskrit and Ayurvedic colleges in the Kedarnath valley. The disposition of the rights and authority of the tirth purohits in this document and its later amendments led to over a century of contention between the Samiti, the community of tirth purohits, and to some degree the rawal over the rights of tirth purohits to collect the ritual fees (Hindi: dan and dakshina) associated with the performance of pujas and other ritual services in and around the temple. The celebration of a successful appeal by the tirth purohit community in this regard was one of the important events of the 2007 season that I spent in Kedarnath (Tandon 2007; India Office 1942; Mukherjea, Ali, and Das 1952).

\section{THE GROWTH AND CHANGE OF YATRA IN GARHWAL}

The general trends in temple administration and the popularization of yatra practice apply to the case of Garhwal. James Lochtefeld (2010, 70-71, 255) has observed that it was the completion of the Upper Ganges Canal in 1854, followed by the inclusion of Haridwar on the Oudh and Rohilkhand Railway in 1886, that would transform Haridwar into a pilgrimage place of year-round importance. This development also made it much easier to begin a yatra to Kedarnath and Badrinath on roads maintained by British administrators. In 2007 and 2008 Rishikesh, just northeast of Haridwar, was the most common point of departure for most groups undertaking the Uttarakhand Char Dham Yatra. British administrators expanded and systematized two related systems of land taxation connected to Kedarnath and Badrinath: gunth and sadavart/sadabart. Gunth refers to lands whose product belongs to the temple as the result of a donation, usually from a king. Sadavart 
"is the term applied to an endowment provided by the land revenue of assigned villages, originally for the purposes of providing with food indigent pilgrims visiting the shrines of Kedarnath and Badrinath" (Walton [1910] 1989, 104). The British used these funds to build and improve roads and provide medical dispensaries along the pilgrimage routes to Kedarnath and Badrinath as a bulwark against the transmission of epidemics. It was during the nineteenth century that yatra to the Uttarakhand Himalaya began to occupy the double space of mass pilgrimage and perilous undertaking from which it now continues to emerge.

George William Traill $(1823,119-20)$, a British official who worked as a commissioner in parts of Garhwal and Kumaon, estimated that Badrinath could receive up to ten thousand visitors in a normal year and up to twenty thousand in a year such as 1820 , when the Kumbha Mela or Ardha Kumbha Mela was taking place, with the arrival of many more prevented only by a cholera epidemic. The adventurer T. J. Saunders $(1844,64)$ claimed that approximately fifteen to twenty thousand yatris visited Kedarnath annually. His assessment about the impact of the recent road (path) built for yatris to Kedarnath by George Traill was prescient, deeply troubling, and ultimately wrong:

The new road has now rendered the temples accessible to all, and in time this very facility of reaching them, which at first you would be disposed to say would be the instrument of increasing and extending fanaticism and idolatry, will, to a moral certainty, tend more than anything else to their overthrow. Juggernath when idolatry was taxed and difficult of approach, was far more popular than it is now; and in half a century, when Kedarnath and Budreenath become better known to the multitude, the pilgrimages for martyrdom by cold and privation will gradually diminish in number, and be succeeded by those of enthusiastic travellers, like ourselves, who undertake this journey of endless toil merely to have an opportunity of admiring the stupendous grandeur of the regions of eternal winter. Mr. Traill, by his removal of the great obstacle in the way of a safe pilgrimage to Kedarnath and Budreenath, hazarded his reputation as a Christian, and subjected himself to the imputation of being an encourager of pagan idolatry.

Saunders claimed that such criticisms misunderstood what he took to be Traill's ultimate purpose: "The surest way of letting idolatry die a natural death, is to make it cheap, and common, and easy of access" (64).

Better transport and the democratization of pilgrimage as a form of public piety saw more visitors of increasingly diverse backgrounds traveling to Kedarnath. The gazetteer writer Walton ([1910] 1989, 56-57), quoting and adding to the account of Edward Atkinson (1886), wrote about Kedarnath:

The pilgrims number 50,000 or 60,000 yearly and come from all parts of India. Formerly devotees used to immolate themselves from the Bhairab Jhap near the temple of Kedarnath, and to the present day an occasional enthusiast wanders blindly up the eternal snows seeking the heaven of the gods. "A popular belief exists that Siva 
frequently makes himself visible on the crest of the great peak and that the wreaths of smoke seen there from below are not the result of whirlwinds gathering up the finer particles of snow, but the smoke of sacrifice made by some highly favoured follower."

Many visitors understood these high regions to be the assembly place of gods, and the natural sounds of trees and avalanches to be the sounds of their activities. The full sensory impact of the region was olfactory as well. Quoting Atkinson, Walton $([1910] 1989,57)$ relates that "the sweet smelling flowers and other vegetation found near the limits of eternal snow frequently overpower the traveler and combined with the rarefaction of the air cause a faintness which may be attributed to superhuman powers." These remarks underscore how the physical environment was understood to signify materially and sensuously the presence of Shiva and other divine powers in the region beyond the temple and in the landscape itself. They also recall the life-ending journey of the Pandavas and highlight the characteristic overemphasis that colonial discourses often gave to forms of religious practice they found to be culturally challenging (Dube 2001, 128-29). Walton ([1910] 1989, 176) also briefly describes the practices of yatris in Kedarnath: "The ceremonies to be observed by the pilgrims are very simple, consisting of a few prostrations, an embrace of the linga and the hearing of a short ritual and discourse from the officiating priest. The pilgrim carries away in copper jars from the sacred pool some water which is highly charged with iron and Sulphur." Also worthy of note is the account of the visit of Sister Nivedita, born Margaret Noble, "the young Irish disciple of the nineteenth-century Hindu reformist and protonationalist Swami Vivekananda" (Roy 2006, 498). Nivedita's account (published in 1928), making up approximately half of an eighty-six-page account of her journey to Kedarnath and Badrinath, blends her wonder at the natural environment, her Orientalist and religious wonder at the ancient richness of Indic pilgrimage traditions, her early nationalist sentiments, and a scholarly interest in the history of Indian religions. She consistently makes assertions regarding the pre- and postShankarite nature of the Shaiva sites she sees on her journey and makes numerous observations regarding the traces of Buddhist presence in Garhwal left in the archaeological record of the temples she visits. ${ }^{8}$ She marvels at the number of yatris, and especially at how many of them are women. She writes, "Who uttered a doubt that India had a place and a life for women? Certainly none who had ever seen a pilgrimage" (Nivedita 1928, 4). In her vibrant and lengthy description of her actual time in Kedarnath, she offers a substantial description of Kedarnath darshan and arati:

Suddenly we were called to see the arati. Darkness had fallen but the mists were gone, and the stars and the snows were clear and bright. Lights were blazing and bells clanging within the temple and we stood without, amongst the watching people. As the lights ceased to swing and the arati ended, a shout of rapture went up from the waiting crowd. Then the cry went out to clear the road, and the rush of the pilgrims 
up the steep steps began. What a sight was this! On and on, up and up, they came, crowding, breathless, almost struggling, in their mad anxiety to enter the shrine, reach the image, and at last, by way or worship, to bend forward and touch with the heart, the sacred point of the mountain! For this half-embrace is what the worship consists of at Kedar Nath ... It was one of the sights of a life time, or [sic] to stand there, and watch the pilgrims streaming in. It seemed as if all India lay stretched before One, and Kedar Nath were its apex, while from all parts everywhere, by every road, one could see the people streaming onward, battling forward climbing their way up all for what?- - for nothing else than to touch God! (40-41)

The peripatetic polymath Rahul Sankrtyayan, father of the Hindi travelogue genre, dwelt on another aspect of yatra to Kedarnath in the early to mid-twentieth century: the difficulty of the ascent. He remarked that, before the improvement to the path made by the British, it was easy to imagine that some yatris visited Kedarnath visited with the intention of "ascending to heaven" in the manner of the Pandavas-that is to say ending their life in or behind Kedarnath-because the combination of altitude and weather made the ascent so difficult and death seem so close (Sānk ṛtyāyana 1953, 424-25). Sankrtyayan's pithy observation, which drew on the anecdotally attested earlier twentieth-century phenomenon in which some yatris would celebrate their own funeral ceremonies before setting out on yatra to the central Indian Himalaya because they did not think they would return (424), neatly summarizes the ways that preexisting practices, ideas, and stories connected to Kedarnath were changing form.

\section{HILL POLITICS}

These yatra-related changes largely involved the way the region was changing to accommodate visitors and the number and diversity of visitors arriving in the region. Corresponding political regional changes are also part of this story. Parallel to the trajectories charted in this chapter thus far were political processes that, after Independence, placed the formerly competitive mountain regions of Garhwal and Kumaon in solidarity with each other as the two hill areas within the large (and mostly plains-based) state of Uttar Pradesh. While there had been demand from "feudal elites" well prior to Indian independence in 1947 for the creation of separate mountain provinces (for example, the demand for a Kumaon Province in 1916) and from "urban elites" in the 1950s, 1960s, and 1970s, these attempts were marked by a lack of grassroots support and competition between Garhwal and Kumaon (A. Kumar 2011, 88-89). As Anup Kumar (2011, 102) notes, this began to change when hill people began to join together in "socio-ecological movements such as the . . University Movement (1971-1973), the Chipko Movement (1973-1980), Nasha Nahi Rozgar Do (Give Jobs Not Intoxication, 1983-1985), Anti-Tehri Dam and the Askot-Arakot Abhiyaan (Askot-Arakot Foot March)." 
These movements, rooted as they were in grassroots concerns about the relationship of local living conditions to the needs and desires of people living outside the region, laid the groundwork for what would become a jan andolan, a people's movement for the creation of a separate state. The connections of residents in the region to the trees and rivers of their own lifeworlds, combined with many different forms of economic, social, and political discrimination they endured at the hands of representatives of the state government, gave these movements a new, unifying power. There was an explosion of activist groups composed of students and/or women with links to other activist groups around the new nation. As these movements gathered steam and as the political ecology of the region continued to fuel the concerns of those involved, the drive for regional autonomy began to be in increased tension with the political vision of the national Congress Party, which had been in power in Uttar Pradesh for decades. A new political party emerged in 1979, the Uttarakhand Revolution Party (Hindi: Uttarakhand Kranti Dal), which allied itself with the national parties who were in competition with the Congress Party: first the Janata Dal and then the Bharatiya Janata Party (BJP) in 1989 (A. Kumar 2011, 116-17). In 1989, in a reflection of changing national political trends, a Janata Dal and BJP-led coalition came into power in Uttar Pradesh and made regionalism part of their political platform, including the passage of an Uttaranchal Statehood Bill in 1991 that recommended a statehood separate from Uttar Pradesh; this was the year that a destructive earthquake in the Uttarkashi district of Garhwal made many paharis feel that their plains-based government did not have the requisite knowledge and commitment (118). Kumar relates, in response to a serious earthquake that struck central Garhwal in 1991, that "the earthquake killed about a thousand people and rendered many more homeless. The official response to the Uttarkashi earthquake became the exhibit one of the aloofness of the government in Lucknow." He further observes that "in public discussions the earthquake brought the people and their socio-ecological concerns together in a moment of crisis" (121-22). These regionally focused changes took place in the context of a national conversation shaped by the Mandal Commission about the creation of legal protections for underprivileged castes and tribes and a rising tide of Hindu nationalism that crested with the destruction of the Babri mosque in Ayodhya, Uttar Pradesh, in 1992.

\section{PRECARITY AND SOLIDARITY}

It was not incidental that governmental response to an earthquake was an important political catalyst to regional "socio-ecological" solidarity. Phenomena such as earthquakes, landslides, and floods have been part of the cultural and physical terrain in the Garhwal Himalaya for a long time. In addition to the severe earthquake in Uttarkashi in 1999, in 1991 Chamoli was at the epicenter of a large 
and destructive quake. The entire region was shaken by an earthquake in 1803, with Uttarkashi, then known by its older name of Barahat, again experiencing terrible damage. It is reasonable to estimate that similar earthquakes have been occurring periodically in the Himalaya for much longer than these recently documented events. Roger Bilham (2004, 842) begins the story of attested earthquakes in the Himalaya with what he terms "a probable Himalayan earthquake reputed to have occurred during the time of enlightenment of Buddha ca. 538 B.C." More locally, in 2014 there was a landslide in the Madmaheswar valley near Ukhimath in which debris flow decimated almost the entire village of Mongoli, a village already affected by the Kedarnath floods in 2013. Major landslides are an annual occurrence whose incidence and intensity rise when there is an earthquake or flood event; in recent decades, they have become relatively more common because of ill-planned cutting and widening of roads (Barnard et al. 2001). Intense rainfalls have been triggering floods and landslides for centuries (Wasson et al. 2013). In the last century, however, the incidence of Glacial Lake Outburst Floods (GLOFs) has been on the rise as increased glacial melt has begun to produce more glacial lakes (Richardson and Reynolds 2000). Small-scale landslides are so common as to be simply part of everyday routine. Bus and jeep passengers in Garhwal have a system for landslide blockage - the passengers on each side of the blocked road will simply walk across the blocked area and get on a jeep or bus that, once it has turned around, will be able to proceed. A friend of mine once described taking a bus ride in Garhwal as a "game of destiny" (Hindi: kismat ka khel).

The Garhwal Himalaya is sometimes described as "fragile," in part because of all of this geological activity (Rizvi 1981). ${ }^{9}$ But fragile is something of a humancentric misnomer that misrepresents both the problems that humans face when living in changeable terrain and the fact that the actions of humans can clearly change that changeable terrain, even in the short term. Change is not necessarily fragility. Historically, humans in Garhwal who have had to live in intimate relation to these conditions developed strategies for successful living (such as not building houses on landslide-prone mountainsides) and, on a range of levels from the economic to the existential, were forced to take into account the inevitability of floods, landslides, and occasionally earthquakes. Vandana Shiva $(1988,184)$ reads the myth of the descent of the Ganga as a metaphorical expression of this situation of necessary sensitivity to the natural environment, seeing in the story a "description of the hydrological problems associated with the descent of mighty rivers like the Ganga, which are fed by seasonal and powerful monsoonic rains" whose forces are mitigated by the mountain forests that are Shiva's hair. A deeprooted sense of contingency comes with living in this Himalayan territory, or in any situation that is marked in the long term by what Jessica Lehman (2014) and many other geographers term "uncertainty." Paharis who have no choice but to deal with this set of conditions experience a sense of solidarity with other paharis. 
The response of the Uttar Pradesh government to the Uttarkashi earthquake of 1991 did not demonstrate a sense of empathy or knowledge about what this event felt like for paharis, so it contributed to currents of socioecological solidarity and resentment against non-pahari outsiders that were already running high.

\section{A NEW STATE}

In 1994 the state government announced new quotas for the admission of historically disadvantaged groups (Other Backward Classes) to state schools and universities. Many, notably students, felt that the new quotas did not fairly reflect the actual percentage of Other Backward Classes present in the mountainous parts of the state. Hunger strikes led to arrests, and arrests led to a shutdown of schools. Students in Srinagar blockaded traffic on the main pilgrimage road, and women joined the students, connecting the protests to the long-standing tradition of female activism in the region (A. Kumar 2011, 135-37). Protests, hunger strikes, and police reprisals spread throughout the region and began to center in Dehra Dun. Protesters were shot in Mussoorie (Garhwal) and Khatima (Kumaon). Eventually one organization, the Uttarakhand Progressive Women's Forum, decided to stage a rally in New Delhi. Activists from all over the region began to converge on Delhi but met with resistance and blockades by the police, most famously at Rampur-ka-Tiraha on the outskirts of Muzzafarnagar city, where an escalation of tension between the protesters and the police became violent, resulting in the death of "about fifteen protesters" and "hundreds" of injuries (A. Kumar 2011, 205). When national newspapers reported that "policemen had assaulted and allegedly raped some women" during the confrontation, riots broke out and "The government imposed 24-hour curfew all over the Uttarakhand region” (A. Kumar 2011, 214). These events created new political momentum for regional autonomy.

In 1996 the BJP became the dominant party in the "mountain districts" in Uttar Pradesh, and in 1997 a BJP-led coalition government called the National Democratic Alliance came to power in the state on a platform that included the creation of Uttaranchal (which would later become Uttarakhand). Uttarakhand and the other two states undergoing similar processes (Jharkand and Chhattisgarh) successfully became states in 2000. The founding vision of Uttarakhand (Uttaranchal) was in crucial ways premised on the commitment to greater sensitivity toward the local living conditions of hill peoples (Hindi: pahari), conditions that are often framed using the idea of "remoteness" (Mathur 2015b). This happened at roughly the time that the region had begun to see an increase in the number of middle-class yatris, the result of an array of developments correlating in important ways to the rise of the middle class in India in the 1980 os and then after economic liberalization in the early 1990s (Sridharan 2004; Brosius 2010). 


\section{NOSTALGIA FOR EARLIER TIMES}

When I discussed twentieth-century history in Kedarnath, people typically did not volunteer opinions, memories, or analyses about the history of the new state and the vision on which it was based. In retrospect, I wonder what I would have heard had I pressed the issue. But political history was not the story that seemed to matter in my conversations about recent history in Kedarnath. What mattered was how Kedarnath itself had been "in earlier times" (Hindi: pehle zamanon men), hence the title of this chapter. During my fieldwork in 2007 and 2008, older tirth purohits would often begin interviews and conversations by telling me their memories of earlier times and their parents' and grandparents' stories about how Kedarnath used to be. When the village was less developed (even only decades ago, they would say), Kedarnath at night was in many respects a fearful place, with most locals unwilling to leave the far smaller enclosure of the built environment of the village during the night for fear that they would attract malevolent supernatural attention. Elderly tirth purohits recall a time when yatris would usually stop for a night halt in Rambara and then go up to Kedarnath and return to Rambara in the same day without even spending the night. The relationship of tirth purohit to patron (Hindi: yajman) in the Kedarnath of these earlier times was, according to these nostalgic memories, a far more intimate and personalized relationship in which the yatri/yajman depended on the tirth purohit for guidance, hospitality, education about Kedarnath, the performance of all ritual needs, and food. The tirth purohit, in accordance with his traditional identity and rights (Hindi: adhikar), was happy to provide these necessary services in unstinting fashion. This was contrasted with the environment of recent years, when the massive increase in the number of yatris was beginning to make this kind of traditional relationship optional and people were not afraid to walk beyond the borders of the Kedarnath village at night. Looking back on conversations about changes in Kedarnath, I have realized that, while the political history of the new state was not explicitly mentioned very often or explicitly correlated to these changes, the sense of nostalgia that came through in these conversations was distinctively regional, a pahari nostalgia.

What were the contexts for these nostalgic memories? The development of motor roads in the Kedarnath valley received special attention as a result of the Sino-Indian border conflict in the 196os, and, just as it had done before, easier access brought more visitors. By approximately the beginning of the sixties, the motor road had reached Guptkashi (Ḍabarāl, n.d., 241). The historian Shivprasad Dabral estimated that approximately one hundred thousand (one lakh) people a year were going to Badrinath just after the middle of the twentieth century (576). In recent decades the number of visitors to Badrinath has oscillated between approximately two and three times the number of visitors to Kedarnath. It is a safe assumption that Kedarnath also received fewer visitors in earlier times, thus giving 
TABLE 2. Annual number of visitors to Badrinath and Kedarnath, 1987-2018

\begin{tabular}{|c|c|c|}
\hline Year & Badrinath & Kedarnath \\
\hline 1987 & 271,850 & 87,629 \\
\hline 1988 & 372,772 & 137,095 \\
\hline 1989 & 370,820 & 115,081 \\
\hline 1990 & 362,757 & 117,774 \\
\hline 1991 & 355,772 & 118,750 \\
\hline 1992 & 412,597 & 141,704 \\
\hline 1993 & 476,523 & 118,659 \\
\hline 1994 & 347,415 & 104,639 \\
\hline 1995 & 461,435 & 105,160 \\
\hline 1996 & 465,992 & 105,693 \\
\hline 1997 & 361,313 & 60,500 \\
\hline 1998 & 340,510 & 82,000 \\
\hline 1999 & 340,100 & 80,090 \\
\hline 2000 & 735,200 & 215,270 \\
\hline 2001 & 422,647 & 119,980 \\
\hline 2002 & 448,517 & 169,217 \\
\hline 2003 & 580,913 & 280,243 \\
\hline 2004 & 493,914 & 274,489 \\
\hline 2005 & 566,524 & 390,156 \\
\hline 2006 & 741,256 & 485,464 \\
\hline 2007 & 901,262 & 557,923 \\
\hline 2008 & 911,262 & 470,048 \\
\hline 2009 & 916,925 & 403,636 \\
\hline 2010 & 921,950 & 400,014 \\
\hline 2011 & 980,667 & 571,583 \\
\hline 2012 & 985,631 & 583,176 \\
\hline 2013 & 497,744 & 312,201 \\
\hline 2014 & 180,000 & 40,832 \\
\hline 2015 & 359,146 & 154,430 \\
\hline 2016 & 624,745 & 309,746 \\
\hline 2017 & 884,788 & 471,235 \\
\hline 2018 (till May 3) & 71,739 & 62,535 \\
\hline
\end{tabular}

SOURCE: Badri-Kedar Temple Committee (n.d.). 
us an idea of how to apply these numbers. The increased ease of access yielded by the extension of drivable roads and attendant infrastructure saw the continued increase in the numbers of yatris journeying to Kedarnath each year (table 2).

As the table shows, the number of visitors to Kedarnath took a fairly sharp jump in 2000, the year that Uttarakhand (first as Uttaranchal) became its own state, separate from Uttar Pradesh. Vishwambhar Prasad Sati $(2013,101)$ observed a 25 percent increase in the number of visitors to Kedarnath between 2000 and 2010. In 2014, by comparison, the state limited the number of yatris per day to five hundred, but the volume of visitor traffic never made enforcing this regulation a problem. The drop in 2013 and 2014 tells its own terrible story. The resurgence that began in 2015 testifies to a humbling combination of human will, economic incentive, and faith.

\section{YATRA TOURISM}

In the mountainous terrain that constituted the majority of the new state, pilgrimage tourism became one of the most important and optimistically regarded factors in the new state-based regional economy (Mamgain 2004, 256-57; 2008). In 1999, around eighty thousand visitors went to Kedarnath. In 2007, in the high season, Kedarnath saw approximately ten thousand visitors per day, and over the course of the seven-month season about five hundred thousand. Valley spaces in the economic catchment area of the Char Dham Yatra and Hemkunt Sahib became spaces primarily oriented around the yatra tourism of middle-class pilgrims, whose expectations for comfortable travel and whose sheer numbers far exceeded the longterm carrying capacity of the mountain environment.

This sudden growth of infrastructure and the nature of economic development connected to pilgrimage and tourism were not sustainable and, as we shall see, unfolded in a manner contrary to the founding vision of the state. It had been known in 2013 for decades, if not longer, that infrastructure development in Uttarakhand, as a primarily mountainous region, needed to take the geologically unstable and relatively inaccessible nature of the region into account in assessments of what scholars of tourism and environmentalists might refer to as the "carrying capacity" and "saturation point" of the region. The setting ought to impose an upper limit on how much the industry ought to grow. Pitamber Sharma (2000, 151), in his study of Badrinath, claimed that prior to the late 1990s pilgrimage tourism did not significantly upset the balance of the Uttarakhand mountain environment and economy because the number of visitors willing to make the difficult trip and their willingness to endure hardship in the name of "religious merit" fit harmoniously with the environmentally aware and economically diversified and localized nature of pahari life, and Jagdish Kaur (1985, 189-90) offered a similar argument about how "new tourism" in Garhwal was moving away from the ideal of "austerity" and toward the ideal of "luxury," thereby placing greater strain on regional resources. 


\section{A SENSE OF REGION}

As Andrea Pinkney has noted in her careful study of recent mahatmya pamphlet texts, the second half of the twentieth century also saw the self-understandings of the region that would become Uttarakhand change significantly in ways that influenced depictions of the Uttarakhand Char Dham. After Independence in 1947 there began to be a greater sense of connection to the world of the North Indian plains. In 1955, Pinkney (2013a, 235) observes, an Uttarakhand Char Dham mahatmya pamphlet had to call its pilgrimage circuit the "little" Char Dham because it was not well known in comparison to the all-India Char Dham. This sense was immediately complicated in the 1960 s by the Sino-Indian War of 1962, which "led the Indian government to target Uttarakhand for intensive infrastructure development, in order to create a defensible buffer zone between the Chinese border and India's plains" (Pinkney 2013, 234-35). Pinkney observes that in the 1960 s the Uttarakhand Char Dham was still primarily understood as a paired set of two dhams: Yamunotri-Gangotri and Kedarnath-Badrinath. In the Kedarnath valley the next several decades saw the extension of the road from Guptkashi ultimately to Gaurikund, and the territory of the Uttarakhand Char Dham as a whole saw much-increased development of infrastructure and roads and the coalescence of the Char Dham into a single "network of four pilgrimage sites" (239). As the records of visitor numbers maintained by the Samiti attest, these changes in infrastructure clearly correlated with the beginning of a rapid rise in the number of visitors to the region. ${ }^{10}$ In the 1980s, Pinkney notes, pamphlets were being offered in a range of languages beyond Hindi- "English, Bengali, Gujarati, Malayalam, Marathi, Nepali, Tamil, and Telugu" - a development attesting to the growing diversity of visitors to the region (242). Further, the 1980s and 1990s saw a modernization of the practice of yatra and the expanding overlap between yatra and the description and promotion of "places to visit with no religious association." The famous hill stations of Mussoorie and Nainital are good examples of tourist destinations in Uttarakhand not primarily known for their religious significance. These changes made the Uttarakhand Char Dham into a single religious "circuit" that "increasingly integrated into a pan-Indian narrative of commercialized sacred space" connected to modern major urban centers $(252,254-55)$.

The single circuit of what can appropriately be called yatra tourism came to be connected to the powerful brand identity of the region as a whole: Dev Bhumi, Land of the Gods. " And at the same time, the label Dev Bhumi referenced the network of local Himalayan deities bound to the landscape who claimed rights over trees, the goddesses whose powerful presences were embedded in earth and water and efficaciously intervened in daily life. This meant that in the "regional modernity" under way in Garhwal broad processes of commodification were blending into place-based networks of divine power that preceded those processes, with the push for the blending being partially provided by yatra tourism. 
Yatra tourism would then come to function as an important signifier both for a set of internal changes about how Garhwalis were relating to (and shaping) their own deity-pervaded natural landscapes and for a set of outward-looking changes as connections to the North Indian plains, along with a greater sense of cosmopolitanism and linkage to the projects of the modern-nation state, were proliferating.

It now may be seen how this broader story bears directly on our historical understanding of Kedarnath in a distinctive way. The same patterns of regulation, management, and extraction that built roads, cut trees, and constructed hydroelectric dams also reshaped cultural terrain. The premodern religious and political landscapes of Himalayan and Shaiva and Shakta sacred geography contentiously ruled by local Himalayan kings joined the broader life of the subcontinent to a greater extent as they were brought under British political, economic, and cultural influence. Independence in 1947 added new nationalist layers, and the processes leading up to statehood in 2000 formalized a sense of regional pahari identity. State involvement (in both colonial and postcolonial settings) with the control and imagining of the natural world (the extraction of natural resources, the building of roads, the damming of rivers, the construction of hill stations) became slowly bound up with the practices of yatra tourism in the late nineteenth and twentieth centuries. The mingling of all of these different forces accelerated in the $1990 \mathrm{~s}$ with explosive results in the early twenty-first century amid the floods, landslides, and earthquakes that were part of the processes of the Himalayan environment, processes whose relationships to human life in the Himalaya were themselves changing in the always emergent production of landscape. I began visiting Kedarnath during this charged time.

\section{THE SEASON}

When I was living in Ukhimath and preparing to live in Kedarnath during my dissertation fieldwork in 2006-8 I sometimes heard the season referred to as a six-month "fair" (Hindi: mela). The season is immediately preceded by a series of melas in the Kedarnath valley that occur in the month of Baisakh: Old (Hindi: Budha) Madmaheshvar, Taltoli Devi (near Lamgaundi), Phegu Devi (near Lamgaundi), Tyudi (Tyudi village near Fata), Jakh (near Jakh Dhar), Maykhanda (Maykhanda), and a small mela in Triyuginarayan that is not the main mela of the year there. Melas in the Kedarnath valley function as some of the most important and fun social events of the year and used to be one of the main times when family and friends who did not live within walking distance would see each other. Gods and goddesses usually make an appearance, but the nature of that appearance varies widely. Taltoli Devi comes out of her temple in a palanquin (Hindi: doli) and "dances." Jakh possesses his human vehicle, who, after a period of intense purification and preparation, runs across hot coal and burning ash. In Maykhanda 
bards sing local versions of the Ramayana and narrate a time, centuries past, when a Gujarati prince came to Kedarnath on yatra and tried (unsuccessfully) to steal sheep and goats belonging to locals. Later in the day, local deities become present in their human vehicles to receive worship and answer questions. There is also a great deal of commerce involved in a mela, particularly involving the sale of sweets, snacks, and toys. Melas are by definition short-term events that are, relative to a normal day, a whirl of socializing, consumption, the viewing of traditional forms of performance and entertainment, and interaction with different forms of divine presence. To call the pilgrimage season in Kedarnath a mela, then, is to acknowledge with dry humor the many ways in which Kedarnath felt like a largerthan-life place. Let us visit the mela. 